\title{
EARLY HORSELESS CARRIAGE DAYS IN IOWA
}

\author{
By JoHN A. ThOMpson
}

Man rode on wheels a long time before he learned to replace horses with horsepower.

The twentieth century was off to a good start before anything but widely scattered experimental automobiles were seen on the dirt roads of Iowa. I say "experimental". because repairs were needed every few miles even after days of greasy mechanical preparation for a long journey of twenty miles or less.

Just as the automobile followed the horse on the dirt roads of Iowa, it also followed the race horse on Iowa's dirt tracks.

The early race cars were likewise "experimental." It was all so new. Every "would be" racing driver was new at the game because there was no mechanical precedent.

Stock model cars were "stripped down" by removing the body, fenders and lamps, leaving only the bare chassis. Early race drivers rode bareback upon the gas tanks. Later racers were "underslung"' to avoid turning over on sharp turns.

Seventy-five to one hundred pounds per square inch was common pressure in tires which blew out frequently and with little wear or provocation.

The high wooden wheels (copied after horse carriage wheels) broke frequently when subjected to hard skids on sharp turns, so racers soon adopted "Houk," "Hayes," and other removable wheels which were stronger and afforded. quick change when a tire blew out.

Cooling systems were not designed for continuous high speeds for long distances, so all sorts of extensions and enlargements were added to old radiators.

Gasoline in those days was nothing like today's highly refined, cracked and scientifically "doped" fuels. Ignition was also not so "hot." So, starting was hard. Carburetor adjustments were frequent and troublesome. A carburetor adjusted for twenty miles per hour would "pop," "cough," "spit" and load up if the car exceeded thirty miles per hour. If the 
carburetor was adjusted for forty miles per hour, then, once stopped, it wouldn't start again, etc.

Every driver had his own formula for "doping" the fuel. Some used ether; some, chloroform; others, a few drops of this or that "more speed liquid." The prescriptions were usually a closely guarded secret, especially if their car "happened" to win a race.

About 1912, one or two factories dared to offer roadsters with "racy lines." Some of these gave vent to the eraze for speed and records were made and broken every few weeks.

The early races were mostly against time between cities or over a given stretch of straight road.

The corners on the public roads were altogether too sharp to permit a turn at more than twenty miles per hour. The increase in auto travel very soon demanded longer turns and less ruts. The main highways were graded and dragged more and more each year. Civic clubs, . Chambers of Commerce, and other promoters soon took up the task of promoting certain main highways and advertised them as the "best route," mostly for the selfish purpose of improving their own trade, but partly because of pride in having the highways passing through their community better kept than those of a neighboring community.

After each rain a committee would get after the farmers along the road and see that all sections were "dragged:" Some of those "dragged" dirt roads at certain seasons were almost as smooth as cement.

A paved highway was not even dreamed of in those days. After a heavy rain, followed by a little traffic (both wagon and auto), ruts twelve to twenty inches deep were not uncommon; usually the track was devious because the first team would drive around the worst mud holes. Then, if a hard freeze came before the mud dried enough to drag, these ruts became the one track trail and many times the ruts would be:-worn smooth, wide and deep.

Iowa highway racing came into being about the time the main dirt road from Davenport to Council Bluffs had been established along a route leading through Oskaloosa and Des Moines, and "was heralded as "the "White Pole Road," and 
later the "Great White Way," by sponsors in various cities along that route.

A rival route was established by an incorporated association of sponsors living in Iowa City, Grinnell, etc. They called the new and better route the "River to River Road."

Each group had its distinctive pole markings to guide the autoist from one crossroads to the next. The "Great White Way" lead the drivers over their route by a white hand-painted band on about every tenth telephone pole. The white band would be about two feet wide and placed about eight feet above the ground.

The "River-to:River Road" association used two black and one white bands of about eight inches in width.

Other road associations sprang up all over the state, each using a different color or style of telephone pole marking to guide the travelers to. the cities favored by the association's new route. When colors gave out, they adopted other markings, such as the "Black Diamond," the "Red Ball," the "Blue X," ete. The telephone poles along Iowa highways were smeared with various colors as high as painters could reach. Then the "Lincoln Highway", established the simple letter " $L$ " marker on .'phone poles, and soon highway markers were adopted to further relieve the confusion.

The rivalry soon became intense between these main trunk highway associations, and private auto owners began record setting and record breaking races from point to point principally to show off their fine roads and boost their communities.

In the fall of 1913, Don McClure of Oskaloosa in his "Oakland Bug". raced Hal Wells of Grinnell in a "Velie Special'" vee crata to prove the "Great White Way" or the "River-to-River Road" the superior route. Wells and the "River Road" enthusiasts won the first trans-state heat.

Many trans-state matched races and solo races against time followed during 1914 and 1915. They spread so fast that police had to stop them in 1916 to pacify the horse and buggy populace.

When the new highway racing fad started, promoting local business interests and thereby serving local civic pride, 
the police of the various cities always cleared the way of traffic and escorted the racers through the eities on their favorite highway. Huge crowds lined the streets and road intersections along the path of the speedsters. Special repairs and supplies including "high test gas," oil, spare tires, food, and hot coffee.were provided all along the line. Long distance telephone lines were kept open to follow the contestants and report their progress throughout the day. Newspapers posted bulletins and painted trans-state maps on their windows with miniature paper autos moving along the map as reports came in. Crowds gathered in the streets and betting was wild and large. This was new and thrilling excitement. It was a brand-new experience of the century and enthusiasm ran high for awhile; but like all new things, cross-state racing soon faded to commonplace, and interest declined.

When denied the free and reckless use of public roads, the "Speed Demons" then took to the half mile race tracksdirt tracks built for thirty mile per hour horses. The turns were flat and the soft turf was soon badly torn up. This created additional strife between the followers of the horse and the followers of "horse-power."

The next development was the highly "banked" one-mile auto race track built of wooden planks. New speed records were made and broken frequently as both tracks and motors were improved from month to month.

Meanwhile, state and county fair visitors inereased their demand for the thrills of mad "horse-power" speed and the spilling of blood that came with most small track auto races; eventually the horse race lovers had to give in to auto races on at least the last day of each fair. Since 1916, the auto racers have held rather a firm hold on these tracks and even today, they seem a necessary part of the state and county fair programs.

On a cool autumn day in September, 1892, the stork played a trick on my father and mother, who lived on a quarter section in Monroe County, Iowa, by thrusting upon them a potential amateur race driver.

In 1904, the first vehicle, using horsepower instead of the power of horses, to frighten his big glaring eyes of twelve 
years seemed to attract so much of his attention that he spent four hours under it, missed school and got a threshing in the end, all for just looking over the first auto ever to come to Avery, Iowa. Before the year was ended he said: "I can build one of those horseless buggies!" And he did. He mounted an old one-cylinder gas engine on a worn out buggy, "swiped" sprockets and drive chain from a neighbor's idle binder and became the proud owner of his first horseless carriage at age fourteen. It didn't win any races, but it did run a few yards now and then; enough to qualify it as a horseless carriage.

After school, he spent a year in a factory and had some garage experience in McClure's "Biggest Garage West of the Mississippi" - became chief mechanic for McClure on the big "Oakland Bug" cross-state racer, but was allowed only to tune up and test the big racer; he was not permitted to drive in the race.

In 1915, he induced George B. Hippee, an auto supply distributor in Des Moines, to allow him to construct a fleet of fast "racy" roadsters for their traveling salesmen. The bright yellow "racers" with three-to-one gears stepped out at sixty miles per hour, which was some speed in those days.

Hippee was proud of his fast yellow "racers," so proud, in fact, that his friend, Roy Perkins, of the "Perkins Service" of Des Moines successfully dared him into a large bet on a matched cross-state race to be held December 16, 1915.

Perkins, like Hippe, also, had a "speed demon" in his employ. Thereupon, Harvey Strong, one of the finest motor mechanics of that period, and no mean race driver, formally challenged your writer, and we tangled with mutual delight. Both were ready to give the other odds. Substantial cash was placed on several barrel heads; and, the race was on.

Highway associations scrambled for favor of both drivers, offering every manner of escort, service and other inducements. Strong chose the "River-to-River Road" from Davenport to Council Bluffs (337 miles) while Thompson chose the Lineoln Highway (386.6 miles), victory to go to the highest average in miles per hour.

It rained the last week of November, 1915, a hard rain 
on top of wet fall. Iowa's famous "gumbo" dirt roads were cut to pieces by heavy wagons and some autos. Ruts were twelve to twenty inches deep. The track was crooked, but fairly wide by December 1, when a hard freeze "set" the roads and traffic during the first few days of December wore the ruts smooth and widened the bottoms to a flat level roadbed which would have been $O$. $K$., if the track had been straight; but, it was as crooked as a dog's hind leg. Deep, crooked ruts, miles of ruts, hundred miles of ruts. Crooked tracks where teams had first turned out sharply around bad mud holes and further wagons and a few small tired autos had followed the sharp detours; curves too sharp for twenty miles per hour had to be negotiated at sixty or seventy.

There was only one way to handle those "mud puddle" detours, just open her up and steer straight. The light racer would "jump" out of the deep rut and when it hit the ground again (if you were right side up) it would land near the track beyond the "mud puddle." So we hoped.

Of course, it shook loose everything in, on, or near the car, including all parts of the human (?) beings in the car. The vacuum bottle full of hot coffee went out first, then John Ball's goggles, cap, pencils and paper. John Ball, then a reporter on the Des Moines Register, rode as mechanic, helper, reporter, etc.

We stopped three times and went back to get his contraptions, but after the third time, Ball just threw away his pencils, etc. and held on for dear life because we were fifteen minutes late, and no race driver ever dallies when behind schedule.

Ultimately, the fenders started going places, we lost the head lamps, the tail lamp, the tools and repairs. Finally, the spare tire and rim worked loose except for one big heavy leather strap at the back. The inflated tire struck the ground, bounded up and struck Ball in the back knocking him out of the car, except for his foot which caught in part of the remaining floor boards. The next bounce threw him back into his seat with a bang.

Lawrence $R$. Klinger, the regular mechanic, was held in reserve at Marshalltown because Ball was regarded as "soft" 
and it was anticipated that he would fold up after the first few hours of rut jumping in zero weather in a really "open". ear. (Even the floor boards were mostly gone by.now.)

But, did Ball get out and run for a hot hotel room? Not John Ball. He just took a deep breath, elevated his chin a little and said, "What are we waiting for?" He not only rode her out the 386 miles, but to add insult to injury, he held in his bare hands a heavy borrowed head lamp, and also held a storage battery between his knees to light the way during the last two hours of the race.

You may wonder why jumping those deep frozen ruts at high -speed didn't break the wheels. Well, be relieved-it did.

Both contestants 'lost wheels. Our right rear wheel went past us like a bat, etc. etc., when we were doing seventy miles per hour between Marion and Cedar Rapids. It barely missed a pedestrian and struck a house like a cannon ball. The brake shoe and steel housing flange were burned off over two inches' and was hot blue for four inches when the little racer came to a'stop a half block down the brick pavement.

The Ford garage at Cedar Rapids had a new rear axle on the scene in fifteen minutes'; a crowd lifted and held up the rear end of the car while the quick change was made. Forty minutes after the accident, the racer was on the heels of a big escort car west bound at full speed.

A wet, freezing sleet covered the goggles which then had to be discarded, only to subject the driver's eyes to direct pelting of the driven sleet. At Boone, bloodshot eyes were bathed in warm borax water; then a hot lunch, gas, oil, a new tire and ready to go.

A 'phone call notified us that Strong had broken a wheel or an axle at Grinnell, delaying him two hours.

Betting which had favored Strong after our Cedar Rapids accident was now switching back in our fàvor.

Ever anxious to avoid a one-sided contest, and not to spoil the sporting interest of hundreds of boosters gathered in the Des Moines streets in front of the windows of the Des Moines Capitol and the Tribune, we ate heartily and ever so slowly in the privacy of the office of the Ford dealer at Boone.

Sensing trouble, the crowd became alarmed at our long 
delay at Boone. No news was let out for over an hour, and soon rumors were current in the crowd that we were injured or drunk or had to overhaul the car; and the betting switched again to Strong, who by now, was "burning up" the River Road near Des Moines.

After an hour and twenty minutes, we pushed Boone behind us and soon again reports of our speed turned the betting odds and a good time was had by all.

The last two hours of that race passed, oh, so slowly, that afternoon and evening-cold? tired? hungry? blind? but we drudged on to victory. Well, anyway, upon our arrival at Council Bluffs, John Ball went directly to the newspaper office and pounded out the story for the Register and your writer went to bed with his boots on-completely fatigued - dead to the world.

But in thirty minutes-tired or no tired-dirty or no dirty - he was awakened by a mad throng from Des Moines who had a banquet and a wild celebration awaiting the victors over in Omaha at the Fontanelle Hotel. Champagne soon dissolved the fatigue, good food satisfied the hunger and good cheer soothed the many bruises.

There ended the December 6, 1915, cross-state highway race!

The experience merely served to whet the appetite for speed. So, early in 1916, the victorious driver built his own little racer out of a 1912 Model T Ford ear: 76 inch wheel base, 28 inch $\times 3$ inch tires, 80 pound per square inch pressure, Boseh magneto instead of spark coils, alloy pistons, handfinished and carefully balanced crank shaft and connecting rods.

This Ford "racer" and its driver won many races and ineidentally a state championship cup during the period prior to the World War. 
Copyright of Annals of Iowa is the property of State of Iowa, by \& through the State Historical Society of Iowa and its content may not be copied or emailed to multiple sites or posted to a listserv without the copyright holder's express written permission. However, users may print, download, or email articles for individual use. 